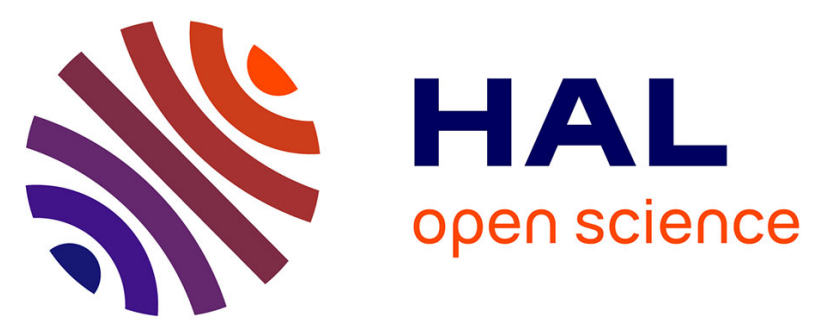

\title{
Magma extrusion during the Ubinas 2013-2014 eruptive crisis based on satellite thermal imaging (MIROVA) and ground-based monitoring
}

Diego Coppola, Orlando Macedo, Domingo Ramos, Anthony Finizola, Dario

Delle Donne, José del Carpio, Randall White, Wendy Mccausland, Riky

Centeno, Marco Rivera, et al.

\section{To cite this version:}

Diego Coppola, Orlando Macedo, Domingo Ramos, Anthony Finizola, Dario Delle Donne, et al.. Magma extrusion during the Ubinas 2013-2014 eruptive crisis based on satellite thermal imaging (MIROVA) and ground-based monitoring. Journal of Volcanology and Geothermal Research, 2015, 302, pp.199-210. 10.1016/j.jvolgeores.2015.07.005 . hal-01390796

\section{HAL Id: hal-01390796 \\ https: / hal.univ-reunion.fr/hal-01390796}

Submitted on 2 Nov 2016

HAL is a multi-disciplinary open access archive for the deposit and dissemination of scientific research documents, whether they are published or not. The documents may come from teaching and research institutions in France or abroad, or from public or private research centers.
L'archive ouverte pluridisciplinaire HAL, est destinée au dépôt et à la diffusion de documents scientifiques de niveau recherche, publiés ou non, émanant des établissements d'enseignement et de recherche français ou étrangers, des laboratoires publics ou privés. 


\title{
Magma extrusion during the Ubinas 2013-2014 eruptive crisis based on satellite thermal imaging (MIROVA) and ground-based monitoring
}

\author{
Diego Coppola ${ }^{\mathrm{a}, *}$, Orlando Macedo ${ }^{\mathrm{b}}$, Domingo Ramos ${ }^{\mathrm{c}}$, Anthony Finizola ${ }^{\mathrm{d}}$, Dario Delle Donne ${ }^{\mathrm{e}, \mathrm{f}}$, \\ José del Carpio $^{\mathrm{b}}$, Randall White ${ }^{\mathrm{g}}$, Wendy McCausland ${ }^{\mathrm{g}}$, Riky Centeno ${ }^{\mathrm{b}}$, Marco Rivera ${ }^{\mathrm{c}}$, Fredy Apaza ${ }^{\mathrm{c}}$, \\ Beto Ccallata ${ }^{c}$, Wilmer Chilo ${ }^{c}$, Corrado Cigolini ${ }^{\mathrm{a}, \mathrm{h}, 1}$, Marco Laiolo $^{\mathrm{f}}$, Ivonne Lazarte ${ }^{\mathrm{c}}$, Roger Machaca ${ }^{\mathrm{c}}$, \\ Pablo Masias ${ }^{c}$, Mayra Ortega ${ }^{c}$, Nino Puma ${ }^{b}$, Edú Taipe ${ }^{c}$ \\ a Dipartimento di Scienze della Terra, Università di Torino, Torino, Italy \\ b Observatorio Vulcanológico del Sur, Instituto Geofísico del Perú (OVS-IGP), Arequipa, Peru \\ c Observatorio Vulcanológico del Ingemmet (OVI), Arequipa, Peru \\ d Université de La Réunion, IPGP, UMR 7154, Sorbonne Paris Cité, La Réunion, France \\ e Dipartimento di Scienze della Terra e del Mare, Università di Palermo, Palermo, Italy \\ f Dipartimento di Scienze della Terra, Università di Firenze, Firenze, Italy \\ $\mathrm{g}$ Volcano Disaster Assistance Program, USGS, USA \\ $\mathrm{h}$ NatRisk, Centro Interdipartimentale sui Rischi Naturali in Ambiente Montano e Collinare, Universita`degli Studi di Torino, \\ Torino, Italy
}

A B S T R A C T

After 3 years of mild gases emissions, the Ubinas volcano entered in a new eruptive phase on September 2nd, 2013. The MIROVA system (a space-based volcanic hot-spot detection system), allowed us to detect in near real time the thermal emissions associated with the eruption and provided early evidence of magma extrusion within the deep summit crater. By combining IR data with plume height, sulfur emissions, hot spring tempera-tures and seismic activity, we interpret the thermal output detected over Ubinas in terms of extrusion rates as-sociated to the eruption. We suggest that the 2013-2014 eruptive crisis can be subdivided into three main phases: ( $i$ ) shallow magma intrusion inside the edifice, (ii) extrusion and growing of a lava plug at the bottom of the summit crater coupled with increasing explosive activity and finally, (iii) disruption of the lava plug and gradual decline of the explosive activity. The occurrence of the $8.2 \mathrm{Mw}$ Iquique (Chile) earthquake (365 km away from Ubinas) on April 1st, 2014, may have perturbed most of the analyzed parameters, suggesting a prompt interaction with the ongoing volcanic activity. In particular, the analysis of thermal and seismic datasets shows that the earthquake may have promoted the most intense thermal and explosive phase that culminated in a major explosion on April 19th, 2014.

These results reveal the efficiency of space-based thermal observations in detecting the extrusion of hot magma within deep volcanic craters and in tracking its evolution. We emphasize that, in combination with other geophysical and geochemical datasets, MIROVA is an essential tool for monitoring remote volcanoes with rather difficult accessibility, like those of the Andes that reach remarkably high altitudes.

* Corresponding author at: Via Valperga Caluso 35, 10125, Torino, Italy. Tel.: +39 11 6705163.

E-mail addresses: diego.coppola@unito.it (D. Coppola),orlando.macedo@igp.gob.pe (O. Macedo),dramos@ingemmet.gob.pe (D. Ramos), anthony.finizola@gmail.com (A. Finizola), dario.d.donne@gmail.com (D. Delle Donne), joseadelcarpio@hotmail.com (J. del Carpio), rwhite@usgs.gov (R. White),wmccausland@usgs.gov (W. McCausland), riky.centeno@igp.gob.pe (R. Centeno), mrivera@ingemmet.gob.pe (M. Rivera), fapaza@ingemmet.gob.pe (F. Apaza), beto.ccallata@gmail.com (B.Ccallata), wchilom@gmail.com (W. Chilo), corrado.cigolini@unito.it (C. Cigolini), marco.laiolo@unito.it (M. Laiolo), ilazarte@ingemmet.gob.pe (I. Lazarte), rmachacca@ingemmet.gob.pe (R. Machaca), pmasias@ingemmet.gob.pe (P. Masias), mortega@ingemmet.gob.pe (M. Ortega),npuma@igp.gob.pe (N. Puma), edtaipe@ingemmet.gob.pe (E. Taipe).

${ }^{1}$ Present address: Institute for Geothermal Sciences, University of Kyoto, Beppu, Japan.

\section{Introduction}

The Andes, one of Earth's highest subaerial mountain ranges, host more Holocene active volcanoes than any other volcanic region in the world (Tilling, 2009) but less than 25 of the $\sim 200$ potentially active volcanoes are continuously monitored (Stern, 2004). Within the last decades, population growth and economic development within the Andean countries drastically increased volcanic risk within the areas surrounding active volcanoes.

The highly elevated $(>4000 \mathrm{~m}$ ) region of southern Peru is a unique example because it hosts seven active volcanoes located at less than $160 \mathrm{~km}$ from Arequipa, the 2nd most important city of Peru (with nearly 1 million inhabitants). The same area was also the site of largest 
explosive eruption in historical times within the Andes (Huaynaputina volcano; AD 1600; Thouret et al., 1999) and, in terms of earthquakes and volcanic eruptions, may be considered one of the most hazardous regions in South America (Degg and Chester, 2005). Progress and refinement of volcano monitoring techniques is therefore strategic to mitigate future volcanic crises.

Space-based thermal observations of volcanic activity (Harris, 2013) represent a useful, safe and inexpensive tool that may strongly improve volcano surveillance, especially at active volcanoes with difficult and dangerous access. A survey performed by Jay et al. (2013) on central and southern Andes reveals that low-amplitude volcanic hotspots detectable from space are effectively more common than expected, especially at volcanoes characterized by low level thermal anomalies such as fumaroles and geysers. For example, by using a high resolution thermal sensor (i.e. ASTER), the authors found hot spots at 4 Peruvian volcanos, Sabancaya (5967 m), El Misti (5822 m), Ubinas (5672 m) and Huaynaputina ( $4850 \mathrm{~m}$ ), with pixel-integrated thermal anomalies spanning from 6 to $13^{\circ} \mathrm{C}$ above background. However, due to the low temporal coverage of the high resolution imagers, a systematic monitoring of these volcanoes is still not sufficient to track daily or weekly variations that may accompany thermal unrest or ongoing eruptive activity.

A new volcanic hot spot detection system, named MIROVA (Middle InfraRed Observations of Volcanic Activity), combines a high sensitivity for detecting small thermal anomalies with the improved temporal coverage typical of moderate-resolution sensors, both factors necessary for near real time monitoring applications (Coppola et al., 2015). The system is based on the analysis of infrared data acquired by the Moderate Resolution Imaging Spectroradiometer sensor (MODIS), and uses the Middle InfraRed Radiation (MIR) recorded at $1 \mathrm{~km}^{2}$ resolution in order to detect, locate and measure the heat radiated from volcanic activity (hereby called volcanic radiative power; VRP in MW). In particular, MIROVA provides thermal maps $(50 \times 50 \mathrm{~km})$ and VRP time-series within 1 to $4 \mathrm{~h}$ of each satellite overpass, thus enabling thermal monitoring of a volcanic target approximately 4 times per day (Coppola et al., 2015).

Since July 2013 MIROVA's observations became operational at three Peruvian volcanoes (www.mirovaweb.it) including Ubinas (5672 m), among the most active volcanoes in Peru (Thouret et al., 2005). Ubinas entered into a new eruptive crisis a few months later, on September 2013, and the whole eruption was monitored both by IGP and INGEMMET Peruvian institutions. This gives us the unique opportunity to relate the thermal flux detected by MIROVA to a series of field observations and other geophysical datasets. After presenting the data acquisition and the chronology of the eruption we will describe the analyzed parameters in terms of eruptive dynamics, with particular emphasis on the contribution of MIROVA in tracking the extrusion of magma within the deep crater of Ubinas. Finally, we will discuss the interaction between the Iquique earthquake (Mw 8.2), that struck the coasts of Chile and south Peru on April 1st, 2014, and the volcanic activity observed at Ubinas.

\section{Ubinas volcano}

Ubinas volcano $\left(16.355^{\circ} \mathrm{S}-70.903^{\circ} \mathrm{W} ; 5672 \mathrm{~m}\right.$ a.s.l.) is considered the most active volcano of Peru, with an average of seven eruptions (VEI 2-3) per century (cf. Thouret et al., 2005; Rivera et al., 2014). The volcano is located beyond the main arc of the Central Andean Volcanic Zone (CVZ), approximately $70 \mathrm{~km}$ East of Arequipa city (Fig. 1). More than 5000 people live within $12 \mathrm{~km}$ from the crater. Together with Huaynaputina and Ticsani volcanoes, Ubinas forms the UbinasHuaynaputina-Ticsani Volcanic Group (UHTVG; Lavallée et al., 2009). Volcanism of this area has been inferred to be strongly ruled by the structural setting, being dominated by a N165 trending normal fault and a sinistral, N130 strike-slip fault (Thouret et al., 2005; Lavallée et al., 2009; Fig. 1). The edifice lies along the western margin of the
Rio Tambo graben (E-W extensional regime) with a $2000 \mathrm{~m}$ altitude gradient between the low-relief high plateau, to West, and the Ubinas valley, to E and SE (cf. Lavallée et al., 2009; Byrdina et al., 2013; Gonzales et al., 2014).

The summit area of the volcano is represented by a steep-wall $1.4 \mathrm{~km}$ wide caldera whose floor is ash covered. An ash cone occupies the central portion of the caldera and is itself truncated to the south by the most recent vent; a triangular funnel-shaped pit-crater $400 \mathrm{~m}$ in diameter and 300 m deep (Rivera, 1997; Thouret et al., 2005; see Fig. 1c). The recent eruptions occurred within the southern pit crater, where fumarolic areas, emitting volcanic gas and steam have been commonly observed during inter-eruptive periods (cf. Gonzales et al., 2014). Before the 2013-2014 episode, the last eruption of Ubinas refers to the 2006-2009 crisis (Rivera et al., 2010, 2014). As previously occurred, this event produced an increasing number of fumaroles, strong degassing, phreatic to phreatomagmatic activity, magma extrusion and vulcanian explosions (2-4 km height columns). The eruptive crisis lasted 3 years, showing a general decline since 2007. The ash fallout affected the 5000 inhabitants and involved the hydrology and the cultivation in an area of $100 \mathrm{~km}^{2}$ (Rivera et al., 2010). As a whole about $7 \mathrm{Mm}^{3}$ of ash has been emitted reaching a distance of $80 \mathrm{~km}$ from the summit (cf. Rivera et al., 2014). According to Rivera et al. (2014) the 20062009 activity represents an "archetype of Ubinas's eruptions" in the last 500 years: repeated ascent of small-volume magma batches $\left(<10 \mathrm{Mm}^{3}\right)$ from a shallow reservoir $(4-7 \mathrm{~km})$ that interact during their ascent with sectors of the hydrothermal system in the shallowest portion of the conduit (Gonzales et al., 2014).

Between 2010 and 2013 the activity was characterized by weak gas emissions (BGVN 38:08) accompanied by mild degassing from the summit crater. On September 2013 a new eruptive episode started (BGVN 38:08).

\section{Data acquisition}

We present more than 1 year of continuous monitoring data acquired between July 1st, 2013 and September 1st, 2014. Five datasets are considered and discussed in the following sections. These consist of: (1) volcanic radiative power, (2) $\mathrm{SO}_{2}$ density, (3) plume elevation, (4) temperature of thermal water, (5) cumulative daily energy of hybrid earthquakes and (6) daily number of seismic events.

\subsection{MIROVA-volcanic radiative power (VRP)}

The MIROVA system is based on MODIS Level 1B data provided in near real time by the LANCE-MODIS system (http://lance-modis. eosdis.nasa.gov/). MODIS images have a nominal spatial resolution of $1 \mathrm{~km}$ (on IR bands) and allow a target volcano to be imaged approximately four times per day. Level 1B granules are analyzed automatically according to five principal steps. These are: (i) data extraction, (ii) cropping and resampling, (iii) definition of region of interest (ROIs), (iv) hot-spot detection and finally and (v) calculation of the "excess" of MIR radiance and volcanic radiative power (VRP) (see Coppola et al., 2015, for details of the processing scheme of MIROVA).

Volcanic radiative power (VRP) is calculated by using the MIR method (Wooster et al., 2003) according to which for any individual "alerted" pixel, the VRP is calculated as:

$V R P_{P I X}=18.9 \times A_{P I X} \times\left(L_{4 a l e r t}-L_{4 b k}\right)$

where $A_{\text {PIX }}$ is the pixel size ( $1 \mathrm{~km}^{2}$ for the resampled MODIS pixels), and $\mathrm{L}_{4 a l e r t}$ and $\mathrm{L}_{4 \mathrm{bk}}$ are the $4 \mu \mathrm{m}$ (MIR) radiance of the alerted pixel/s and background, respectively. When two or more pixels (a cluster of pixels) are alerted, the total radiative power is calculated as being the sum of each single VRP PIX.

As discussed by Coppola et al., 2015, a number of issues must be taken into account when using the data automatically provided by 

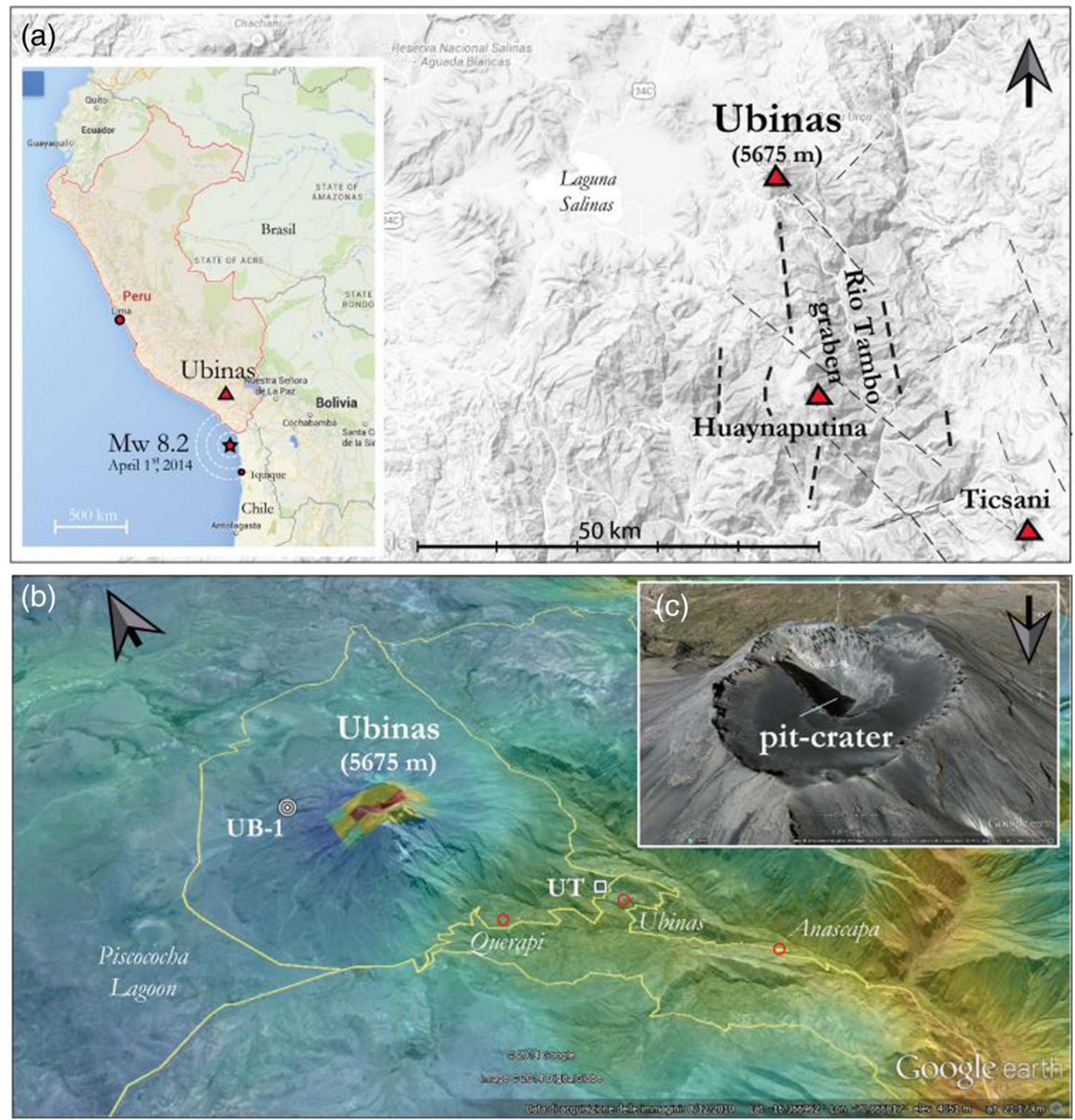

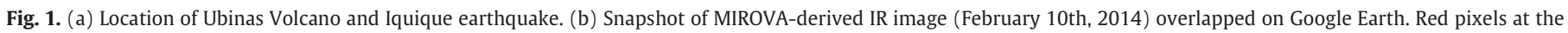

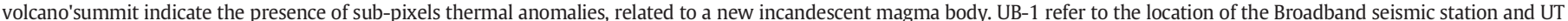
refer to the location of "Ubinas thermal" hot spring. (c) Details of the Ubinas caldera with the deep southern pit-crater (image from Google Earth).

MIROVA. In particular, the presence of clouds and the viewing geometry angle may strongly affect the thermal signal detected by MODIS. While the clouds may completely absorb the IR radiation from the ground, the radiating source located at the bottom of a deep crater (as in the case of Ubinas) may remain undetected when the satellite zenith angle is very high (i.e. $>30^{\circ}$ ). For these reasons the visual inspection of each image was performed routinely during the eruption allowing to interpret the thermal signal case by case, and to discard one hotspot which was related to a fire that occurred on September 19th, 2013 on the south flank of the volcano.

Between July 2013 and September 2014 MIROVA detected hotspots in 62 images, with VRP ranging from 1 to $37 \mathrm{MW}$ (Fig. 3a). Based on the analyzed data we estimated that the 2013-2014 eruption of Ubinas radiated approximately $5.5 \times 10^{13} \mathrm{~J}$ into the atmosphere. An example of selected images processed by MIROVA throughout the eruption is given in Fig. 2

\section{2. $\mathrm{SO}_{2}$ density (OMI)}

$\mathrm{SO}_{2}$ density in Dobson Units (DU) is calculated from Ozone Monitoring Instrument (OMI) images and published daily through the Aura Validation Data Center website (AVDC, http://avdc.gsfc.nasa.gov/). For this study we used the daily average of $\mathrm{SO}_{2}$ density values (Fig. $3 \mathrm{~b}$ ) estimated for the Planetary Boundary Layer PBL-SO ${ }_{2}$ column with center of mass altitude of $0.9 \mathrm{~km}$ (http://so2.gsfc.nasa.gov/docs.html), just above the crater area of Ubinas volcano and within $50 \mathrm{~km}$ radius. As noted on this website, some of the values may be potentially biased by noise due to South Atlantic Anomaly (SAA).

\subsection{Plume elevation}

The estimation of the daily maximum plume elevation (Fig. 3c) have been performed during the period July 1st, 2013 to March 9th, 2014 by a 
(a) $10-F e b-2014$ 03:05:00

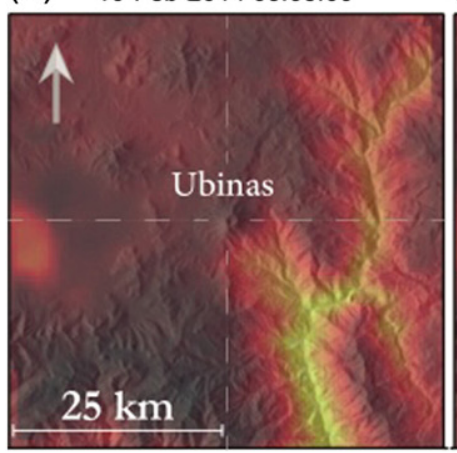

(b) $10-F e b-2014$ 06:10:00

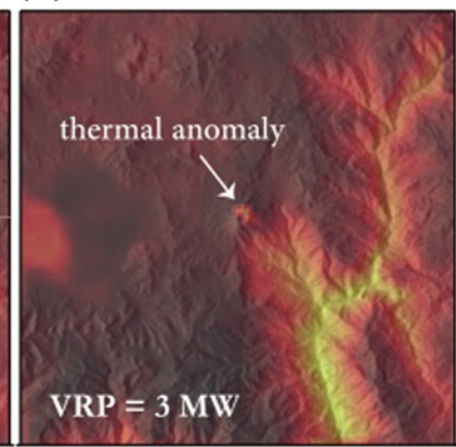

(C) $26-F e b-201406: 10: 00$

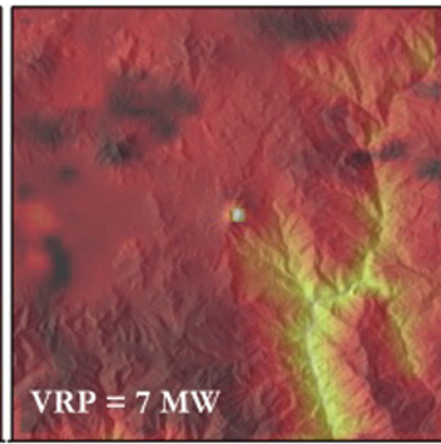

(d) 12-Mar-2014 03:15:00

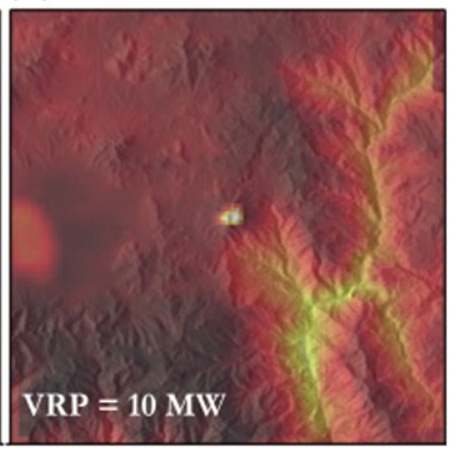

(e) 14-Mar-2014 06:10:00

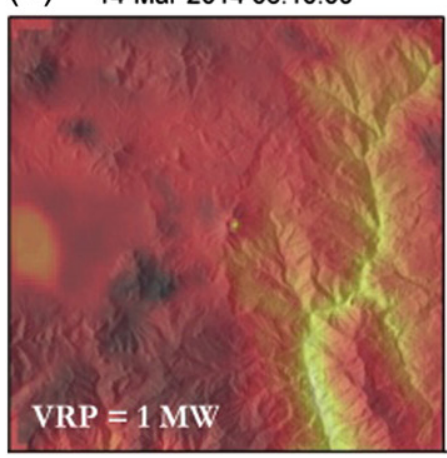

(i)

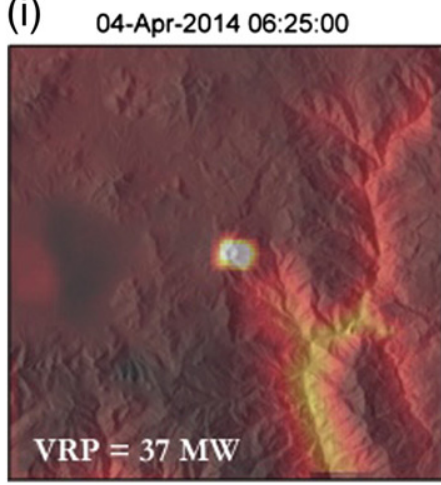

(f) 21-Mar-2014 03:10:00

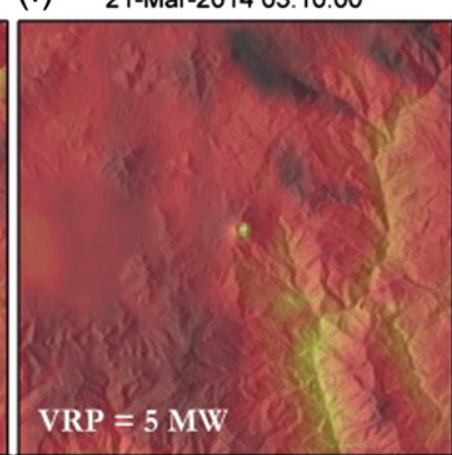

(I)

11-Apr-2014 03:30:00

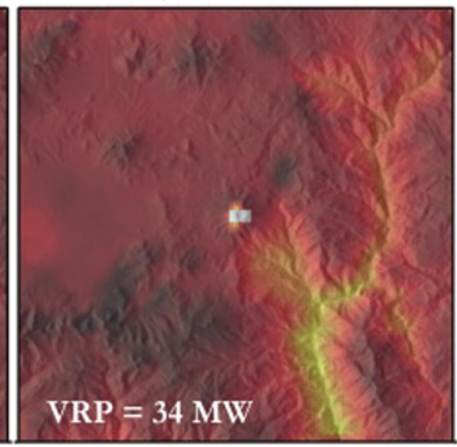

(g)

26-Mar-2014 03:30:00

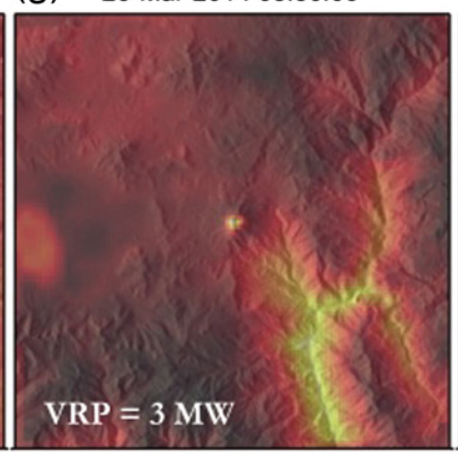

(m) 15-Apr-2014 03:05:00

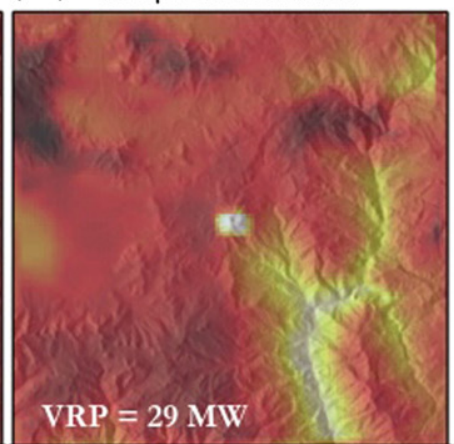

(h) $30-$ Mar-2014 06:10:00

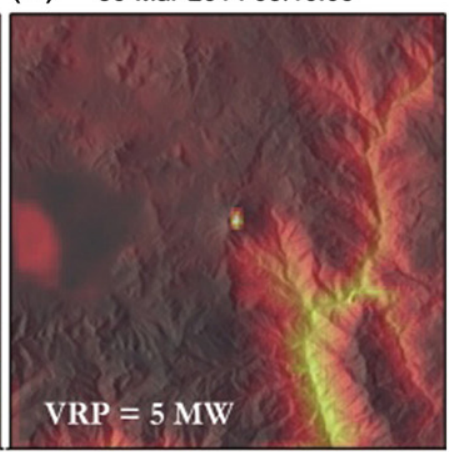

(n) 08-May-2014 06:15:00

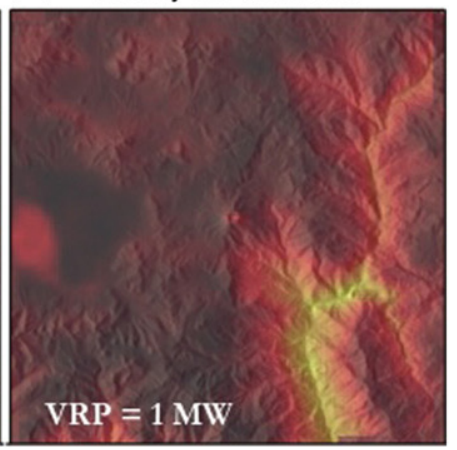

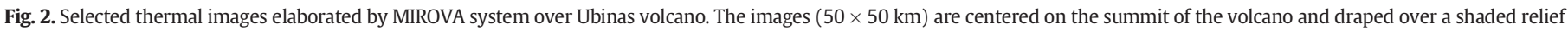
map. For more information on thermal maps produced by MIROVA, please refer to Coppola et al., 2015).

local assistant from Ubinas village and after March 10th, 2014 by way of a video camera installed $28 \mathrm{~km}$ to the west of the active vent.

The video camera (Campbell Scientific CC5MPX) records one picture of 5 megapixels every $30 \mathrm{~s}$. These images are sent to Arequipa by telemetry.

\subsection{Temperature of thermal waters}

Temperature in the thermal spring of "Ubinas Thermal", located $\sim 5.6 \mathrm{~km}$ SE from the volcano's summit (UB1 in Fig. 1; Gonzales et al., 2014), has been measured every 5 min by a data logger (Tinytag Aquatic 2). In this survey, we plot the temperatures measured every day at $4.00 \mathrm{AM}$ (local time) in order to avoid any fluctuations due to variations of solar radiation (Fig. 3d).

\subsection{Cumulative daily energy of hybrid earthquakes}

The Ubinas volcano seismic network is a telemetric network maintained by the OVS-IGP. This network consists of four permanent digital telemetric stations (UB1, UB2, UB3 and UB4) distributed over the entire volcanic cone, between 4850 and 5000 masl. Two stations (UB1 and
UB2) are equipped with Guralp CMG-40T, 3C broadband sensors, and the other two (UB3 and UB4) with Lennartz LE-3Dlite short period sensors. All digitizers are RefTek-130.

The analysis and classification of seismic signals recorded by the network, the determination of the seismic energy, the location of events, etc., is performed daily using mainly the UB1 seismic data, UB1 being the most reliable station, situated $2.5 \mathrm{~km} \mathrm{NW}$ of the active vent.

The energy has been calculated by using the following equation:

$E_{\text {seismic }}=2 \pi r^{2} \rho c \frac{1}{A} \int S^{2} U(t)^{2} d t$

(Johnson and Aster, 2005) where $r$ is the source-station distance, $\rho$ is the density, $c$ is the P wave velocity, $A$ is the attenuation correction, $S$ the seismic site response correction and $U(t)$ is the particle velocity. The source is fixed below the active vent. By setting $\rho=$ $2600 \mathrm{~kg} \mathrm{~m}^{-3}, c=3000 \mathrm{~m} \mathrm{~s}^{-1}, A$ and $S$ were fixed at 1 .

During the current eruption all types of seismic events have been observed like Volcano-tectonic (VT), Long period (LP), hybrid (events having high and low frequencies), tremors, explosions and exhalations. 


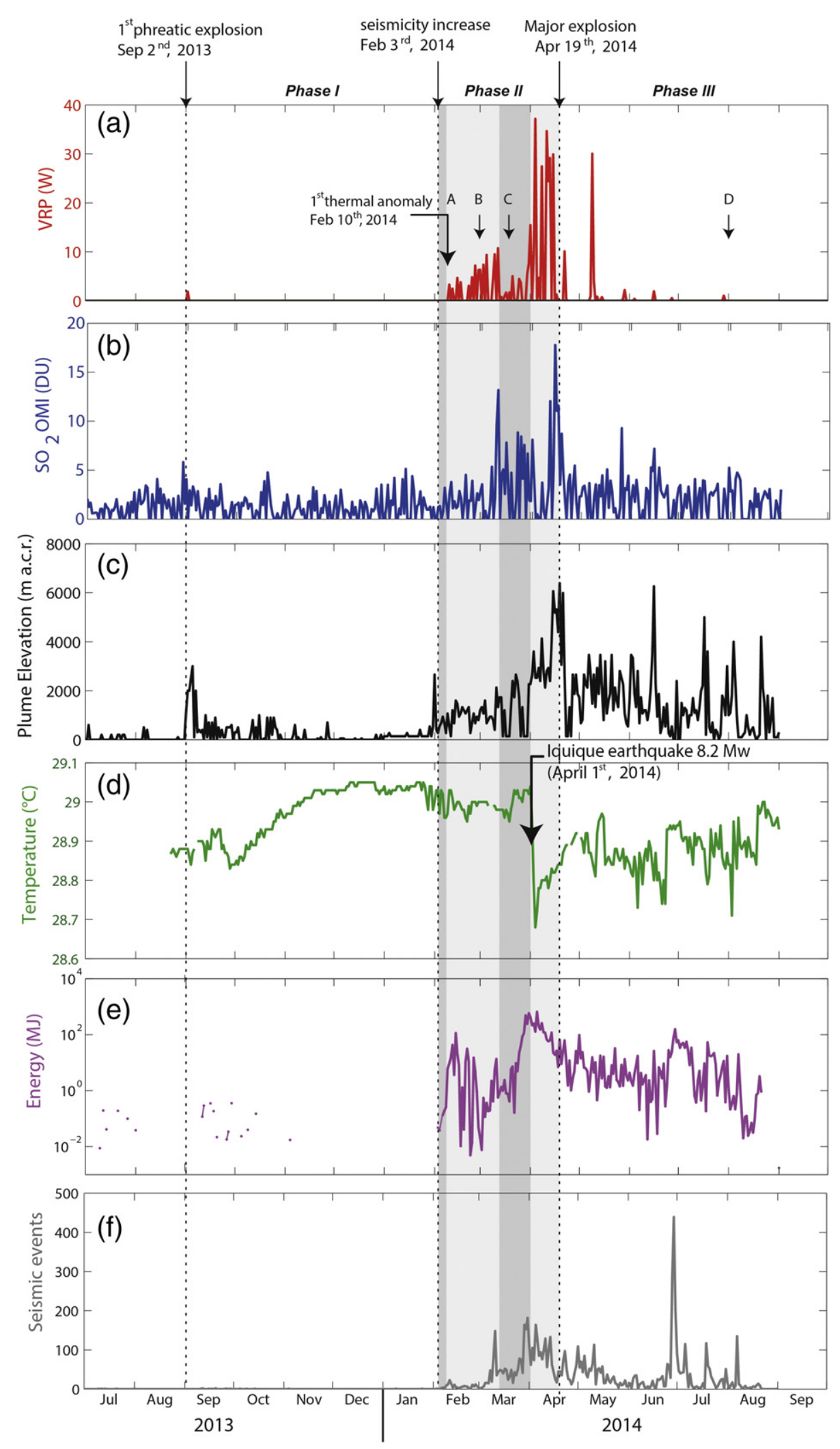

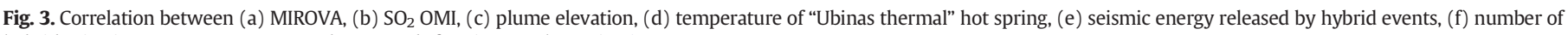
hybrid seismic events. "A", "B", "C" and "D" stands for pictures shown in Fig. 4.

During the 7 months with maximum activity, February to August 2014, these events were recorded with mean rates of $44 \mathrm{VTs} /$ month, $5223 \mathrm{LPs} /$ month, 1104 hybrids/month, 164 explosions or exhalations/month and 6 h daily of tremor. All these events occurred near the surface by the crater zone, except VTs which were located between 1 and $3 \mathrm{~km}$ deep below the crater zone.

During the stage of magmatic eruption, characterized by intense eruptions of tephra, the most important signals are earthquakes of the 
hybrid type, which have been detected and registered from the second week of February onwards (Fig. 3). Since these features have been associated with magma ascent to the crater (White et al., 1998; White, 2011) the OVS decided to conduct a surveillance of the eruption based primarily on the cumulative daily energy (Fig. $3 e$ ) and on the daily rate (Fig. 3f) of such hybrid type earthquakes.

\section{Results}

Based on the recorded parameters and the observed phenomena the 2013-2014 eruption of Ubinas has been subdivided into three main phases (Fig. 3).

On September 2nd, 2013 at 03:46 UTC, a phreatic explosion generated an ash plume that rose 1.5 to $2 \mathrm{~km}$ above the crater. A few minutes after the explosion, at 04:00 UTC, the MIROVA system detected the first thermal anomaly since the beginning of real time observations (Fig. 3a). This explosion was the first of a short sequence of phreatic events that occurred between September 2nd and 7th, and marks the beginning of the Phase I. In the following months, occasional puffs of steam and gases rose typically $500 \mathrm{~m}$ above the crater without producing any thermal anomaly detectable by MIROVA. However, between September and December 2013, the "Ubinas Thermal" (UT) hot spring started to increase its temperature (Fig. 3d). On January 2014 plume height was persistently below $500 \mathrm{~m}$ although anomalous $\mathrm{SO}_{2}$ concentrations (above $10 \mathrm{DU}$ ) were detected by OMI on a few occasions (Fig. 3b and c).

An increase in seismic activity started on February 3rd, 2014 and marks the beginning of the Phase II (Fig. 3e and f). Daily energy of hybrid earthquakes suddenly increased on 9th February (rising for the first time above $5 \mathrm{MJ}$ ) and was followed, on February 10th, by the first thermal anomaly detected by MIROVA after September 2013 (Fig. 3a). Note than the picture taken on February 11th, 2014, does not allow seeing the bottom of the crater (Fig. 4a). However, the MODIS image of February 10th was acquired with a very low satellite zenith angle (Fig. 2b) allowing the detection of magmatic anomalies better than those collected by means of visual observations from the caldera summit.

After a peak on February 14th (114 MJ; Fig. 3e) the energy of hybrid earthquakes started to decline, although thermal anomalies were regularly detected and increased over time, reaching about 6-7 MW on March 1st. These thermal detections occurred only under nearzenithal viewing geometry (satellite zenith $<35^{\circ}$ ) thus suggesting that the "radiating source" was located at the bottom of the deep summit crater and likely corresponded to a growing lava body. A field survey of March 1st confirmed, for the first time, the presence of an elongated body of incandescent lava at the bottom of Ubinas crater that, by that time, measured about 30-40 $\mathrm{m}$ in diameter (Fig. 4b). During the following days the VRP continued to increase due to the growth of the lava body within the deep crater, reaching about $12 \mathrm{MW}$ on March 12th. At the same time a moderate growth of sulfur emissions and plume height was recorded by OMI (Fig. 3b and c). Throughout March 2014 the explosivity of the eruption slightly increased (plume height reached more than $2000 \mathrm{~m}$ and sulfur emission between 10 and $35 \mathrm{DU}$ ) but a clear reduction in thermal emissions was detected by MIROVA between 14 and 31 March (VRP of 2-7 MW, Fig. 3a, b, c). The visual inspection of the MODIS images allowed us to discard the presence of clouds or volcanic plumes as the origin of this decrease (Fig. 2). Hence, we infer that a noticeable reduction of magma flux entering the crater characterized this period, although incandescence was still visible at the surface (Fig. 4c). Interestingly, this sharp decrease of the thermal output in mid-March 2014 was almost coeval with a marked escalation of seismicity (Fig. 3f) with hybrid's energy release reaching $580 \mathrm{MJ}$ on March 31st, 2014 (Fig. 3e).

On April 1st, 2014 at (23.46 UTC) a 8.2 Mw earthquake struck off the coast of Chile, $365 \mathrm{~km}$ south of Ubinas volcano (Fig. 1). The earthquake triggered a tsunami of up to $2.1 \mathrm{~m}$ (that hit the town of Iquique, $95 \mathrm{~km}$ south east from the epicenter) and affected regions of Tacna, Moquegua
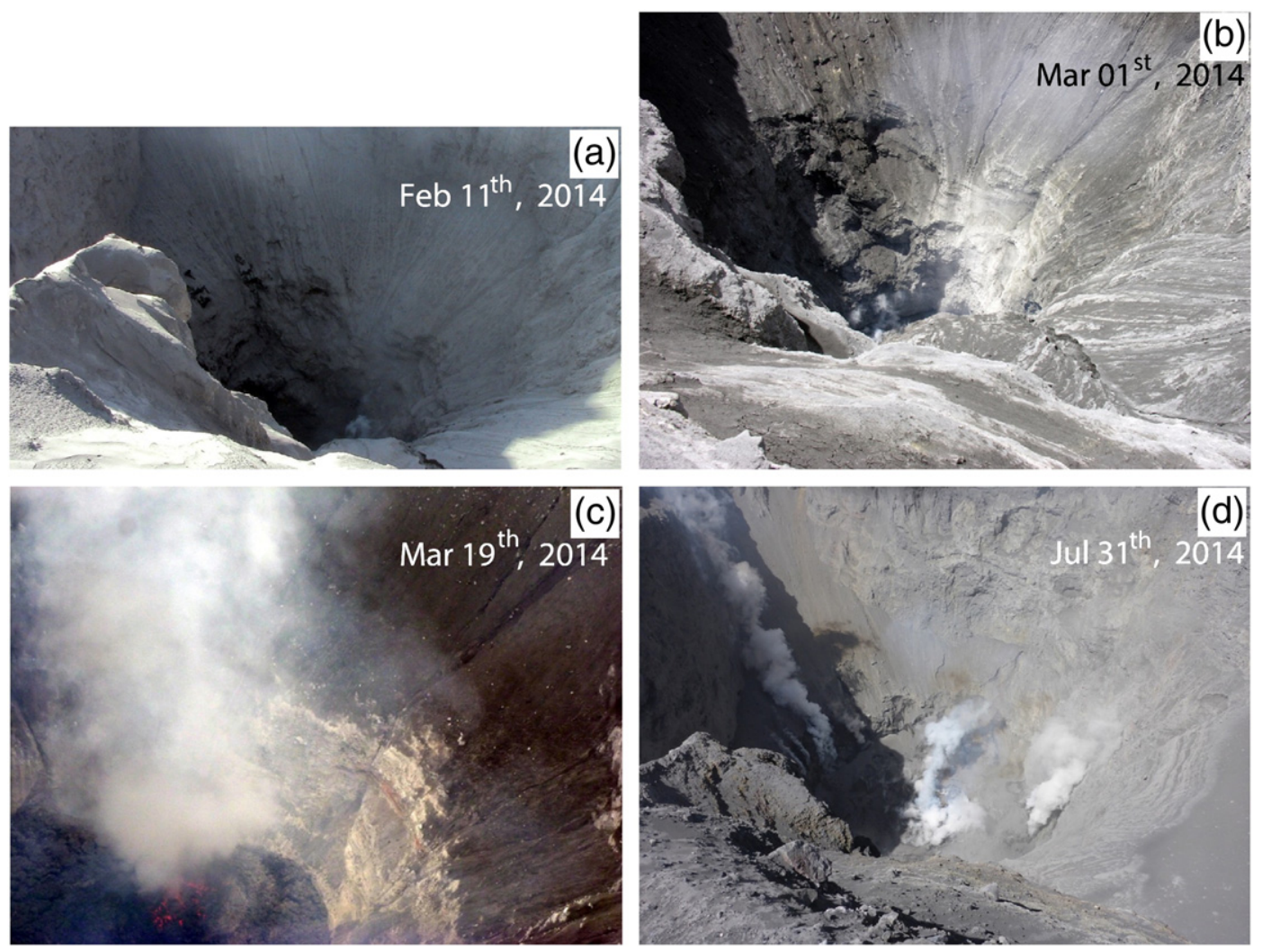

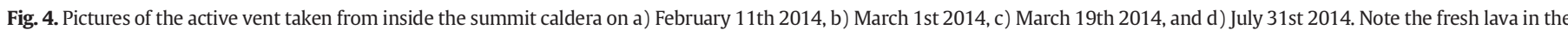
bottom on the crater in c. 
and Arequipa, in South Peru. The Iquique earthquake was felt in Arequipa town (intensity of III-IV) and eventually affected the plumbing system of Ubinas as suggested by the perturbation of the monitored parameters (Fig. 3).

The hot spring at "Ubinas Thermal" station (UT) recorded this event with a sharp drop of the water temperature (Fig. 3d). Evaluation of precipitation data recorded at Ubinas village (courtesy of Meteorological Service of Peru) allowed us to rule out that the decrease of temperature resulted from the rainfall. More likely the temperature drop may have resulted from a temporary mixing of fresh and thermal water, as well as from a permeability change induced by transient stresses (Manga et al., 2012). Temperature drop is typical of the response of many wells and springs in a variety of environments to the seismic waves from distant earthquakes (Hill et al., 2002) as for example observed in the past years at Ubinas and Misti volcano (IGP internal Reports for June, 23th, 2001).

A major change in the eruptive behavior of Ubinas was also recorded by seismic and MIROVA data. Indeed, after several days of increasing trend, seismicity inverted its tendency just after the earthquake, starting to decline in both hybrid's energy release (Fig. 3e) and number of events (Fig. 3f). At the same time the thermal activity within the crater had strongly intensified reaching $37 \mathrm{MW}$ on April 4th, 2014. This was the highest thermal anomaly recorded during the eruption and occurred only 3 days after the $8.2 \mathrm{Mw}$ earthquake (Fig. 3a). In the following days several thermal detections reached more than $20 \mathrm{MW}$ and were accompanied by the most explosive phase, characterized by multiple explosions ejecting incandescent tephra and blocks around the crater. In this period the ash plumes reached altitudes of more than $4000 \mathrm{~m}$ and were coupled with sulfur emissions as high as 45 DU (Fig. 3b, c).

A major explosive event occurred on April 19th 2014, where blocks of fresh basaltic andesite magma, $40-50 \mathrm{~cm}$ in size, were ejected up to $2.6 \mathrm{~km}$ from the active vent. The volcanic plume rose more than $6 \mathrm{~km}$ above the crater, and a block of $5 \times 4 \times 2 \mathrm{~m}$ has been found inside the summit caldera, at $660 \mathrm{~m}$ from the active vent.

This explosion marks the end of the Phase II and the transition into the Phase III. Thermal output at the summit crater dropped abruptly after the major explosion, and the detection of weak thermal anomalies (about 1 MW) became sporadic between May and September 2014 (Fig. 3a). At the same time, the explosive activity gradually declined although it was punctuated by distinct explosive events of decreasing intensity. On May 9, at 03:50 (UTC), an isolated thermal anomaly of 30 MW was detected (Fig. 3a) and resulted from the hot material ejected during one coeval explosion.

The abrupt drop of thermal emissions after the explosion of April 19th was likely associated with the massive disruption of the magma plug, extruded within the crater during the previous explosive phase. Actually, the explosion cut the head of the magma column (strongly deepening the thermal source) which however continued to feed tens of minor explosive events during Phase III. Field observations on July 31 st confirmed that the lava body at the bottom of the crater had disappeared (Fig. 4d), even though moderate explosions and $\mathrm{SO}_{2}$ emissions were still significant (Fig. 3b and c). On the other hand, after the earthquake-induced drop of temperature, the hot spring UT gradually returned to pre-earthquake temperatures (yet showing multiple minor fluctuations, Fig. 3d). As a whole the Phase III consisted of a waning eruptive period and by September 2014 the activity of Ubinas consisted only of weak plume emissions and sporadic low altitude explosions (Fig. 3b and c).

\section{Discussion}

The phreatic explosions of September 2013 mark the beginning of the Phase I and possibly reflect the first interaction between a new ascending magma batch and the large hydrothermal system located under the Ubinas crater (Gonzales et al., 2014).
It is worth noting that the temperature of the "Ubinas thermal" hot spring increased significantly during this phase (Fig. 3d), probably reflecting a period of shallow magma intrusion inside the edifice and its interaction with the thermal waters stored within the hydrothermal system. On the other hand, the increase in the energy of hybrid events on February 3rd, 2014 (Fig. 3e), just followed by summit thermal anomalies (on February 10th, 2014), clearly indicates that 166 days after the first phreatic explosion, the magma had reached the bottom of the summit crater. By assuming that the base of the hydrothermal system is located 1500-3000 m below the summit (Gonzales et al., 2014), we may infer that during this intrusive stage the andesitic magma batch rose to very shallow depth with an average velocity of $1-2 \times 10^{-4} \mathrm{~m} \mathrm{~s}^{-1}$.

Overall, during the most intense "eruptive" period (Phase II), we observe a good correlation of the peaks and trends between thermal output, $\mathrm{SO}_{2}$ emissions, and plume elevation (Fig. 2). Notably, our datasets reveal that since the first detection of magma at the bottom of the crater (on February 10th), all the above parameters share a general increasing trend throughout the Phase II (Fig. 3) that was apparently amplified by the Iquique earthquake (discussed below).

Although thermal, $\mathrm{SO}_{2}$, and plume elevation sample distinct eruptive processes (i.e. heat, gas and ash release), it's interesting to note that all these parameters are somehow related to rate of magma ascent within the shallow volcanic conduit (Gonnermann and Manga, 2013). For example, under certain assumptions, space-based thermal flux released by active lava bodies may be converted into estimates of Time Averaged lava Discharge Rates (TADR; Harris and Baloga, 2009; Dragoni and Tallarico, 2009; Coppola et al., 2013) thus providing a way to calculate volumetric flux of effused-extruded lavas (see next section). On the other hand, the $\mathrm{SO}_{2}$ emissions have been widely used to calculate magma degassing rates (i.e. Allard et al., 1994) and in some cases may provide constraints into the magma supply rate (by using the so called "Petrologic Method"; Shinohara, 2008). Nonetheless, during explosive eruptions, plume height has been commonly correlated to Mass Eruption Rates (MER) (Morton et al., 1956; Wilson et al., 1978; Sparks et al., 1997; Mastin et al., 2009) thus providing a further way to evaluate magma production rates occurring during explosive events. Accordingly, we may infer that the Phase II was characterized by a general acceleration of magma eruption rates that culminated into the paroxysmal phase of April 19th, 2014.

\subsection{Extrusion rates and volumes from thermal data}

Coppola et al. (2013) proposed a simple method to provide firstorder estimates of time-averaged lava discharge rates (TADR) from MODIS-derived VRP. This is based on an empirical parameter called "radiant density" $\left(\mathrm{c}_{\mathrm{rad}}\right)$ :

$$
T A D R=\frac{V R P}{c_{\text {rad }}}
$$

where TADR is in $\mathrm{m}^{3} \mathrm{~s}^{-1}$, VRP is in $\mathrm{W}$, and $\mathrm{c}_{\mathrm{rad}}$ is the radiant density, expressed in $\mathrm{J} \mathrm{m}^{-3}$

The radiant density approach relies on the fact that under a given discharge rate, basic, intermediate and acidic lava bodies radiate thermal energy differently because of their different bulk rheology. Based on the analysis of several distinct worldwide eruptions, the authors suggest that the radiant density of a lava body can be predicted $( \pm 50 \%)$ on the basis of the silica content of the erupted products:

$c_{\text {rad }}=6.45 \times 10^{25} \times\left(X_{\mathrm{SiO}_{2}}\right)^{-10.4}$

where $\mathrm{X}_{\mathrm{SiO} 2}$ is the silica content (wt.\%) of the erupted magma. For Ubinas andesite, here we used a silica content of 56 wt.\% (Rivera, pers. comm.), and we calculated a radiant density comprised between $2.1 \times 10^{7}$ and $8.5 \times 10^{7} \mathrm{~J} \mathrm{~m}^{-3}$. Accordingly, we estimated that $1.5 \pm$ $0.75 \mathrm{Mm}^{3}$ of magma have been extruded between its first appearance 
at the surface, on February 10th, and the major explosion of April 19th, 2014 (mean output rate of $0.25 \pm 0.12 \mathrm{~m}^{3} \mathrm{~s}^{-1}$ ).

A more detailed analysis reveals that, although characterized by a general increasing trend, the extrusion of magma was somehow cyclic, with at least three distinct stages (Fig. 5a). The first stage (Phase IIb) was recorded between February 10th and March 12nd, when the extrusion rate gradually increased from $0.1 \pm 0.05$ to $0.31 \pm 0.15 \mathrm{~m}^{3} \mathrm{~s}^{-1}$. The second stage (Phase IIc) followed a drastic reduction of magma extrusion on March 14th, and was characterized by output rates that remained below $0.2 \mathrm{~m}^{3} \mathrm{~s}^{-1}$ up to the end of March (Fig. 5a). The third stage started after April 1st, and was characterized by the sudden increase of extrusion rate (up to $1.4 \pm 0.02 \mathrm{~m}^{3} \mathrm{~s}^{-1}$ on April 4th) that persisted above $1 \mathrm{~m}^{3} \mathrm{~s}^{-1}$ up to the major explosion of April 19th (Phase IId). It is worth noting that during this intense extrusive and explosive phase the magma plug was probably continuously extruded and disrupted by the recurrent explosions so that by the end of May 2014 no magma body was present at the bottom of the crater (Fig. 4d). Sporadic thermal emissions were also recorded during the Phase III. However, due to the poor continuity of the thermal signal we don't consider this phase as extruding significant magma volume within the pit crater. Instead, we regard the above values as a minimum estimate for the erupted magma volumes, essentially extruded during the Phase II. Accordingly, we may estimate that a minimum of $1.5 \pm 0.75 \mathrm{Mm}^{3}$ of ash and tephra should have been produced by the continuous disruption of the magma body at the bottom of the pit crater, especially throughout the most intense Phase IId. By comparison, about $7 \mathrm{Mm}^{3}$ of ash tephra was erupted during the long-lasting 2006-2009 eruptive crisis throughout hundreds of vulcanian explosions (Rivera et al., 2014).

\subsection{Thermal and hybrid seismic activity comparison}

The comparison between hybrid seismic and thermal activity recorded during the Phase II reveals a more complex eruptive dynamic and outlines some mutual relationships between these parameters

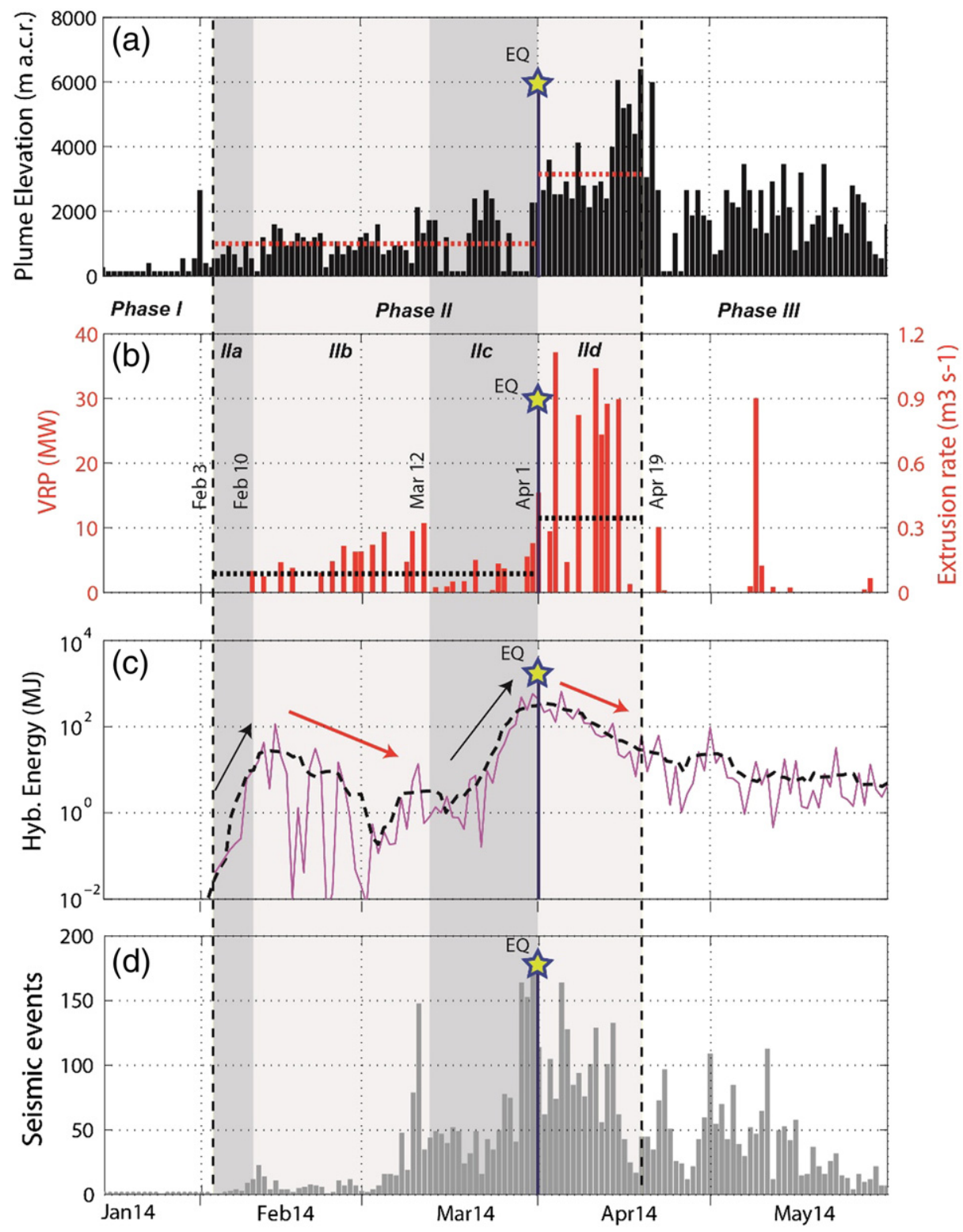

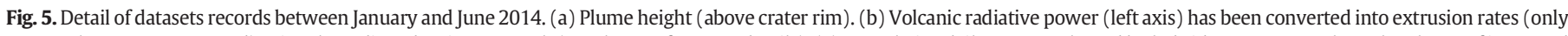

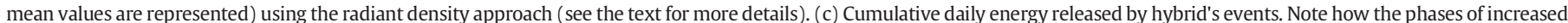

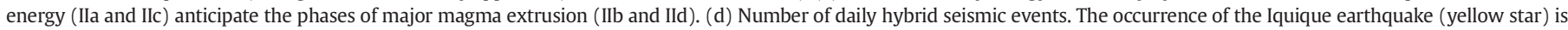

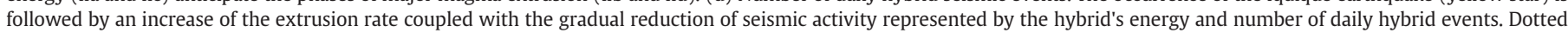
horizontal lines in (a) and (b) represent pre- and post- earthquake mean values outlining a 2- to 3-fold increase in the extrusive-explosive activity. 
(Fig. 5). In fact, the increase of hybrid's energy and the heightening of daily seismicity seem to have systematically "preceded" the cycles of major magma extrusion at the summit crater. For example, in early February 2014, when the conduit was still "closed" (no signs of thermal activity), the occurrence of few but energetic hybrids suggests that the magma had to overcome a high resistance before eventually appearing on the surface (Phase IIa; Fig. 5). On the other hand, after the first "opening" of the conduit (i.e. after February 10th), the magma rose almost easily (increasing extrusion rate) and hybrid's energy decreased accordingly (Phase IIb; Fig. 5). Once again these trends inverted since March 12th, when the reduction of the extrusion rate was coupled with a renewed and stronger increase in seismic activity. This suggest that the ascent of magma in this period was somehow "reduced" (or blocked), because of obstruction(s) within the conduit or, eventually, because the magma was too viscous to flow out. In our view, the Phases Ila and IIc might reflect stages of pressure build-up within the plumbing system where the slow ascending magma had to push hard (increasing daily hybrid's energy) to open the conduit (Phases Ila) or to extrude magma at low rates (Phases IIc). The earthquake of April 1st occurred at this critical stage and may have contributed to unblocking the conduit and promoting the most intense activity at the vent (Phase $2 \mathrm{~d}$; see also next section). It is worth noting that, after the earthquake, both the energy of hybrids and the number of seismic events decreased regularly, thus suggesting a general depressurization of the shallow magmatic system during the highest extrusive phase as well as during the following waning phase (Fig. $5 \mathrm{~b}$ and c).

Ottemöller (2008) found similar correlations during the 2003 extrusive eruption at Soufrière Hills Volcano (SHV), whereby higher energy releases of hybrid events reflected increased pressurization during periods of low extrusion rates. Conversely, lower energy releases have been inferred to be associated with rapid extrusion and reduced pressurization. Thus, the cyclic magma extrusion observed at Ubinas volcano is not uncommon, and may be explained by non-linear processes related to degassing, crystallization and rheological stiffening of magma, as observed in many other dome-building eruptions (Denlinger and Hoblitt, 1996; Melnik and Sparks, 1999; Costa et al., 2007).

\subsection{Possible interaction between the Iquique earthquake and Ubinas volcano}

Regional earthquakes have been proved to be able to interact with volcanoes by triggering new volcanic unrest (Hill et al., 2002), by perturbing the medium in the vicinity of a volcanic conduit (Battaglia et al., 2012; Manga et al., 2012; Lesage et al., 2014), or, by causing several-fold increases in thermal output (Delle Donne et al., 2010), eruption rates (Harris and Ripepe, 2007) and/or gas transfer (Cigolini et al., 2007), at already erupting volcanoes.

Our datasets suggest that at least four parameters recorded during the Ubinas eruption (water temperature at Ubinas thermal station, thermal flux at the summit crater, plume height and hybrid seismicity) appear to have been perturbed by the M 8.2 Iquique earthquake (Fig. 3). While the temperature drop at the Ubinas Thermal station (Fig. 3d) may represent a local response of the shallow hydrothermal system to the seismic waves, it is possible that the other three parameters reflect a response of the magmatic system to the megathrust earthquake. In particular, the response of Ubinas volcano consisted on a 2- to 3-fold increase of volumetric flux and plume height, coupled with a decrease in the amplitude and rate of hybrid earthquakes (Fig. 5).

Seismic waves travel to great distances without losing much of their energy (Hill et al., 2002; Delle Donne et al., 2010) so that dynamic stress induced by their passage may have effectively influenced activity at Ubinas volcano. Transient stress perturbations may in fact promote nucleation, growth and ascent of gas bubbles, acting as a vesiculation pump (Manga and Brodsky, 2006; Harris and Ripepe, 2007) thus causing the enhanced magma extrusion and explosive activity as effectively observed at Ubinas just after the Iquique earthquake (Fig. 5).
Delle Donne et al. (2010) statistically constrain the maximum distance for triggering an eruption at a given volcano, which is strictly dependent on the magnitude of the earthquake. These authors suggest that the orientation of the seismogenic faults, in respect to the location of the volcano, can also play a role in facilitating the triggering mechanism (i.e., by means of focusing the radiated energy in a strikeparallel direction). The Iquique megathrust earthquake ( $\mathrm{Mw}=8.2$; distance $=365 \mathrm{~km}$; fault strike: $348.9^{\circ}$; Lay et al., 2014) fully meet the cited conditions, since the seismogenic fault that generated the earthquake is characterized by a directivity perfectly compatible with the location of Ubinas (Fig. 6). This supports the hypothesis that the transient stress changes may have accelerated the eruptive processes at Ubinas, already operative at the time of the triggering earthquake.

On the other hand Bonali et al. (2013), among others, suggest that earthquake-induced "unclamping" (normal stress reduction within the magma pathway) may also promote an increase in magma flux at volcanoes that are already in a critical state. To test this possibility, we estimated the normal stress change and volumetric dilatation induced by Mw 8.2 Iquique earthquake, by using Coulomb 3.3 software (e.g., Toda et al., 2005). As input fault model we used the Finite Fault Results (Bassin et al., 2000; Ji et al., 2002) computed by G. Hayes (NEIC-USGS) available at: http://comcat.cr.usgs.gov/earthquakes/ eventpage/usc000nzvd\#scientific_finite-fault.

To calculate the normal stress change we assumed a shallow $(\sim 2 \mathrm{~km}$ deep), nearly vertically dipping and $165^{\circ} \mathrm{N}$ oriented dyke (consistent with the geology) and a deep magma chamber located within 5 and $10 \mathrm{~km}$ below the surface (Lavallée et al., 2009; Rivera et al., 2010). Results of the analysis suggest that the Iquique earthquake may have produced a weak clamping, in the order of only 0.03 bar (Fig. 7a), at the shallow feeder dyke, coupled with a minor volumetric compression of deep magma chamber (Fig. 7b). Accordingly, we may conclude that the earthquake did not cause a normal stress reduction (Bonali et al., 2013) but, conversely, it may have induced only a very small compression of the Ubinas plumbing system. However, given its low amplitude, it is unlikely that this weak "clamping" could have promoted the "squeezing" of the magma filled pathway throughout a small but stable deformation (e.g. Nostro et al., 1998; Bautista et al., 1996).

On the other hand our results suggest that Ubinas volcano may have responded promptly to the Iquique earthquake ( $<3$ days) by increasing the eruption rate at the vent and by decreasing the shallow seismicity surrounding the conduit (Fig. 5).

At Soufrière Hills Volcano, faster extrusion rates were systematically observed during deflation periods, the latter being characterized by decreasing hybrid earthquakes (Green and Neuberg, 2006). Accordingly, we suggest that the lowering in the hybrid energy release was not directly related to the earthquake itself, but more likely to the acceleration of the extrusive-explosive processes occurring at the vent. In turn the increase in discharge rates induced a pressure drop within the magma plug and caused the gradual waning of seismicity.

Besides, several other Peruvian volcanoes, in a critical or quiescent state, satisfy the criteria described by Delle Donne et al., 2010 (distance and strike alignment) and might have been also perturbed by stress changes induced by the Iquique earthquake (Fig. 6). These include Sabancaya and El Misti, among the most active volcanoes of Peru in the last century. Further investigations will better clarify if the seismic waves caused by the Iquique earthquake had sufficient energy to trigger a response in fumarolic emission or volcano seismicity at these volcanoes.

\section{Conclusions}

The combined use of satellite and field monitoring techniques allowed us to track the evolution of the 2013-2014 eruptive crisis of Ubinas volcano. The eruption has been subdivided into three main phases based on a set of six parameters and the observed activity. While Phase I is related to a period of shallow magma intrusion, the 

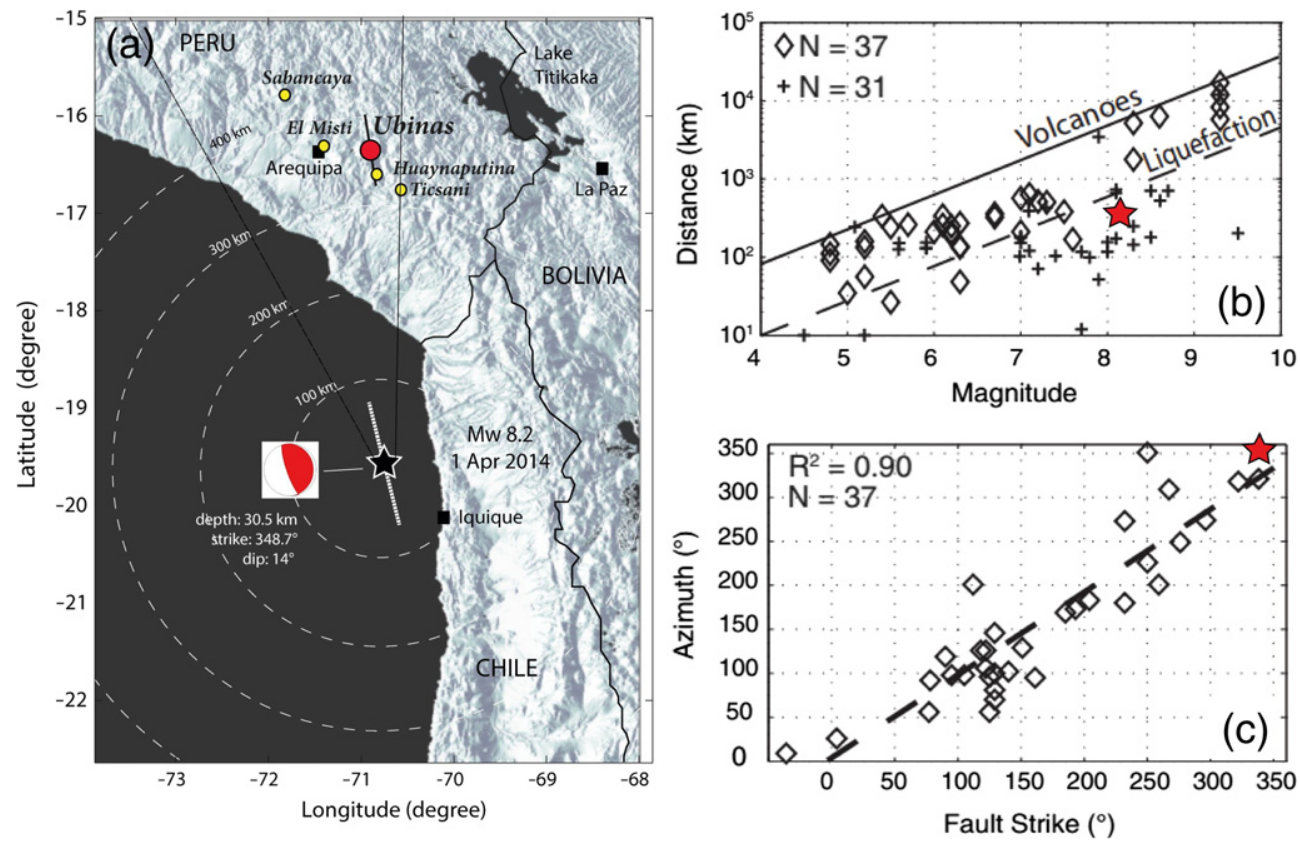

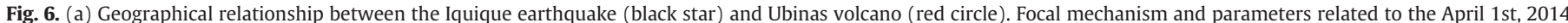

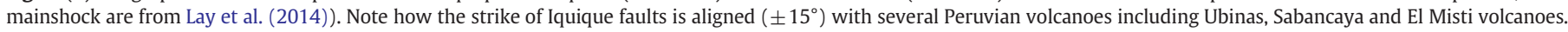

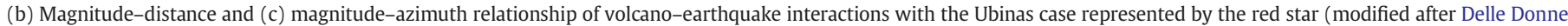
et al., 2010).

other two phases were ascribed to stages of waxing (Phase II) and waning (Phase III) eruptive activity, respectively.

In particular, the space-based observations performed by the MIROVA system provided the first evidences of magma extrusion

\section{(a) Normal stress change (bar,unclamping positive)}

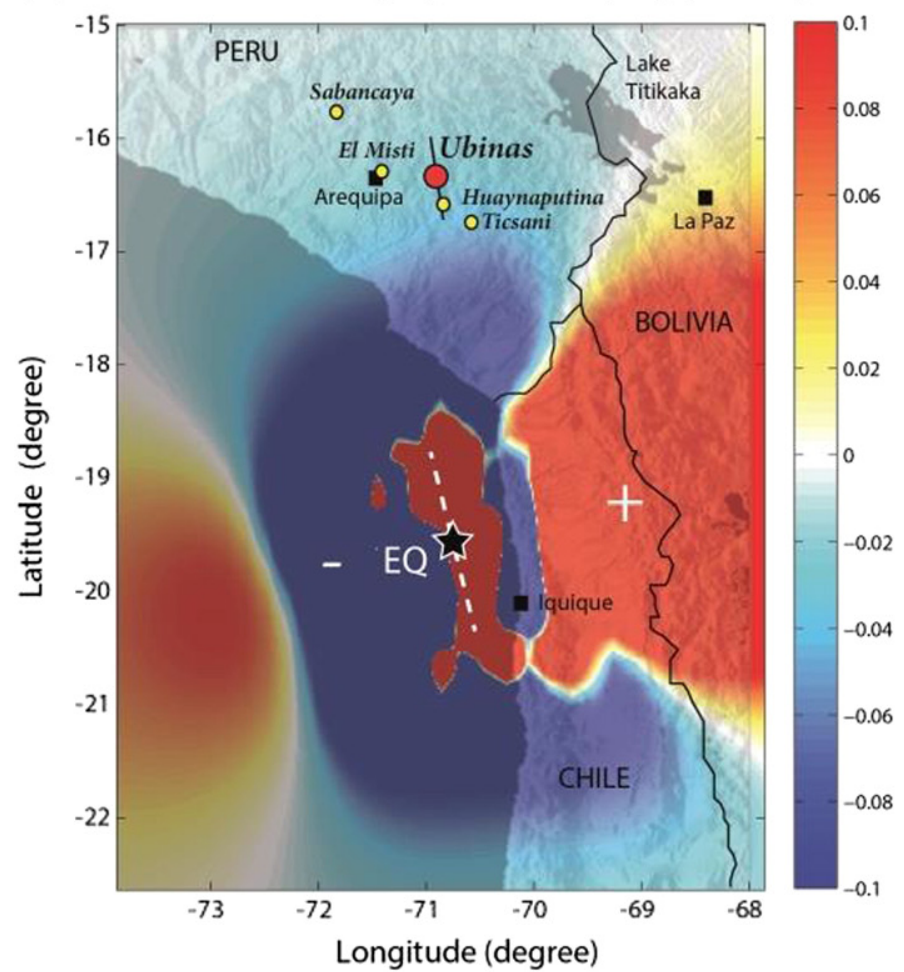

Specified faults: 165/90/-90 Depth: 2.00 km Friction: 0.4 within the bottom of the summit pit-crater and allowed to constrain extrusion rates during the most intense eruptive phase (Phase II). We estimated that between February and April 2014, at least $1.5 \mathrm{Mm}^{3}$ of magma were extruded during week-long cycles and were abruptly (b) Dilatation

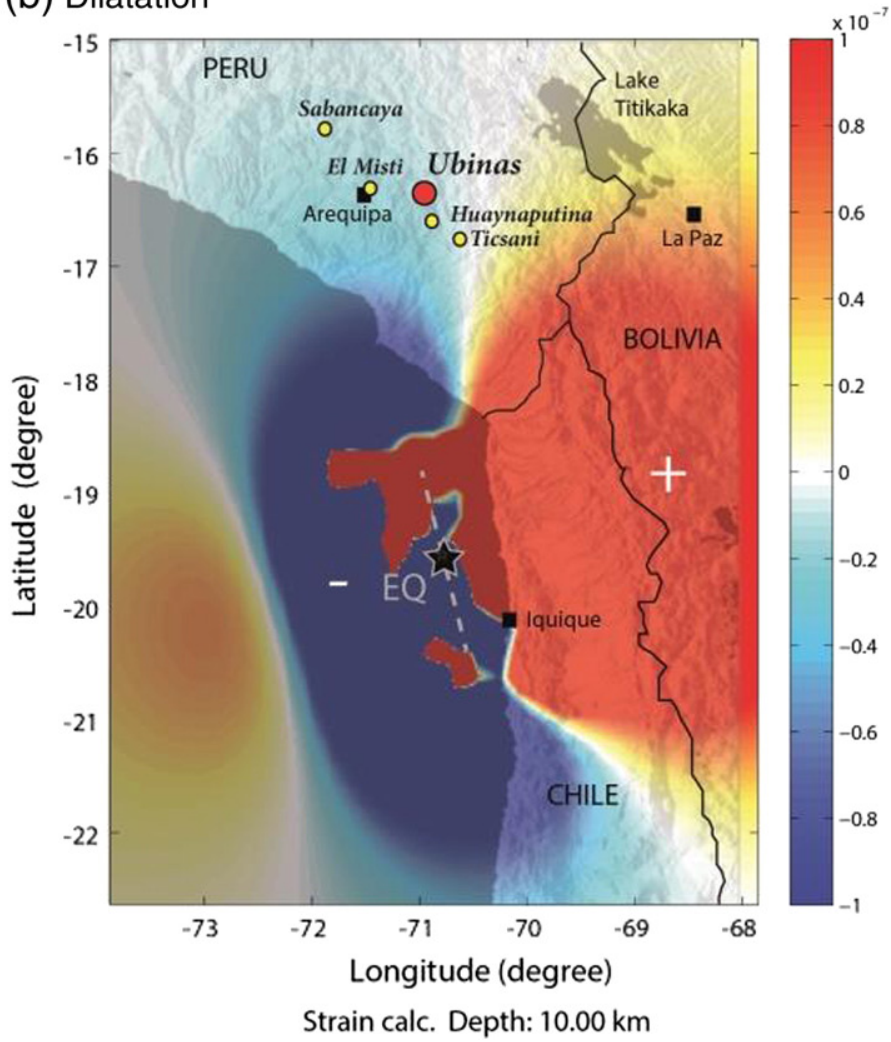

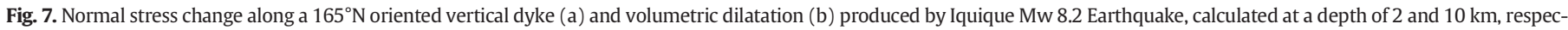

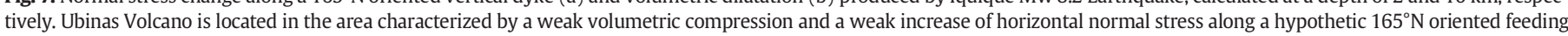
vertical dyke. 
disrupted during the major explosion of April 19th, 2014. Nonetheless, during the Phase II we recognized a general acceleration of all the eruptive processes (magma extrusion, plume height, $\mathrm{SO}_{2}$ emission) which were apparently perturbed by the occurrence of the Iquique earthquake (Mw 8.2) on April 1st, 2014. A preliminary analysis suggests that the prompt 3 -fold increase of the extrusion rate was principally a response to the dynamic stress changes induced by the earthquake, and may have favored a general depressurization of the shallow magmatic system associated to the decreasing hybrids seismic activity.

The observations provided by MIROVA demonstrate the capability to track the presence of magma within deep craters, and allow us to better understand the extrusive processes by correlating MODIS data with other datasets, such as plume emissions and seismic activity (i.e., the energy released by hybrid events). In conclusion, we hereby demonstrate that MIROVA is an additional and efficient tool for monitoring safely, and in near real time, extrusive-explosive volcanoes with hard and dangerous access.

\section{Acknowledgements}

MIROVA is a collaborative project between the Universities of Turin and Florence (Italy), and is supported by the Italian Civil Protection Department. Additional funds were provided by MIUR, Fondazione Cassa di Risparmio di Torino and Fondazione Compagnia di San Paolo di Torino. The seismic study was financed by the APNOP Meta 022 and the PP068 Meta 007 of the OVS-Instituto Geofísico del Perú. We acknowledge L. Wilson for the editorial handling. We thank, S. Byrdina and J.F. Lénat for their constructive comments. We are grateful to D. Hill for discussions and suggestions on an early version of this manuscript. We particularly thank M. Alvarez and J. Acosta for field observations. We acknowledge the LANCE-MODIS system (http://lance-modis. eosdis.nasa.gov/) for providing Level 1B MODIS data. This is IPGP contribution number: 3644 . Any use of trade, firm, or product names is for descriptive purposes only and does not imply endorsement by the U.S. Government.

\section{References}

Allard, P., Carbonelle, J., Mètrich, N., Loyer, H., Zettwoog, P., 1994. Sulphur output and magma degassing budget of Stromboli volcano. Nature 368, 326-330. http://dx.doi. org/10.1038/368326a0.

Bassin, C., Laske, G., Masters, G., 2000. The current limits of resolution for surface wave tomography in North America. Eos. Trans. AGU 81, F897.

Battaglia, J., Métaxian, J.-P., Garaebiti, E., 2012. Earthquake-volcano interaction imaged by coda wave interferometry. Geophys. Res. Lett. 39, L11309.

Bautista, B.C., Bautista, Ma.L.P., Stein, R.S., Barcelona, E.S., Punongbayan, R.S., Laguerta, E.P., Rasdas, A.R., Ambubuyog, G., Amin, E.Q., 1996. Relationship of regional and local structures to Mount Pinatubo activity. In: Punongbayan, R.S., Newhall, C.G. (Eds.), Fire and mud: eruptions and lahars of Mount Pinatubo, Philippines. Philippine Institute of Volcanology and Seismology/University of Washington Press, Qezon City, Philippines/Seattle, WA, pp. 351-370.

Bonali, F.L., Tibaldi, A., Corazzato, C., Tormey, D.R., Lara, L.E., 2013. Quantifying the effect of large earthquakes in promoting eruptions due to stress changes on magma pathway: the Chile case. Tectonophysics 583, 54-67. http://dx.doi.org/10.1016/j.tecto.2012.10. 025.

Byrdina, S., Ramos, D., Vandemeulebrouck, J., Masias, P., Revil, A., Finizola, A., Gonzales Zuñiga, K., Cruz, V., Antayhua, Y., Macedo, O., 2013. Influence of the regional topography on the remote emplacement of hydrothermal systems with examples of Ticsani and Ubinas volcanoes, Southern Peru. Earth Planet. Sci. Lett. 365, 152-164.

Cigolini, C., Laiolo, M., Coppola, D., 2007. Earthquake-volcano interactions detected from radon degassing at Stromboli (Italy). Earth Planet. Sci. Lett. 257 (3-4), 511-525.

Coppola, D., Laiolo, M., Piscopo, D., Cigolini, C., 2013. Rheological control on the radiant density of active lava flows and domes. J. Volcanol. Geotherm. Res. 249, 39-48. http://dx.doi.org/10.1016/j.jvolgeores.2012.09.005.

Coppola, D., Laiolo, M., Cigolini, C., Delle Donne, D., Ripepe, M., 2015. Enhanced volcanic hot-spot detection using MODIS IR data: results from the MIROVA system. In: Harris, A.J.L., De Groeve, T., Garel, F., Carn, S.A. (Eds.), Detecting, modelling and responding to effusive eruptions. Geological Society, London, Special Publications 426. http://dx.doi.org/10.1144/SP426.5 (first published on May 14, 2015).

Costa, A., Melnik, O., Sparks, R.S.J., Voight, B., 2007. Control of magma flow in dykes on cyclic lava dome extrusion. Geophys. Res. Lett. 34, L02303.
Degg, M.R., Chester, D.K., 2005. Seismic and volcanic hazards in Peru: changing attitudes to disaster mitigation. Geogr. J. 171 (2), 125-145.

Delle Donne, D., Harris, A.J.L., Ripepe, M., Wright, R., 2010. Earthquake-induced thermal anomalies at active volcanoes. Geology 38, 71-74. http://dx.doi.org/10.1130/G30984.1.

Denlinger, R.P., Hoblitt, R.P., 1996. Cyclic eruptive behavior of silicic volcanoes. Geology 27 (5), 459-462

Dragoni, M., Tallarico, A., 2009. Assumptions in the evaluation of lava effusion rates from heat radiation. Geophys. Res. Lett. 36 (8), L08302. http://dx.doi.org/10.1029/ 2009GL037411.

Gonnermann, H.M., Manga, M., 2013. Magma ascent in the volcanic conduit. In: Fagents, S.A., Gregg, T.K.P., Lopez, R.C. (Eds.), Modeling Volcanic Processes: The Physics and Mathematics of Volcanism. Cambridge University Press, pp. 55-84.

Gonzales, K., Finizola, A., Lénat, J.F., Macedo, O., Ramos, D., Thouret, J.C., Fournier, N., Cruz, V., Pistre, K., 2014. Asymmetrical structure, hydrothermal system and edifice stability: the case of Ubinas volcano, Peru, revealed by geophysical surveys. J. Volcanol. Geotherm. Res. 276, 132-144.

Green, D., Neuberg, J., 2006. Waveform classification of volcanic low frequency swarms and its implication. J. Volcanol. Geotherm. Res. 153, 51-63.

Harris, A.J.L., 2013. Thermal Remote Sensing of Active Volcanoes: A User's Manual. Cambridge University Press, p. 736.

Harris, A.J.L., Baloga, S.M., 2009. Lava discharge rates from satellite-measured heat flux. Geophys. Res. Lett. 36 (19). http://dx.doi.org/10.1029/2009GL039717.

Harris, A.J.L., Ripepe, M., 2007. Regional earthquake as a trigger for enhanced volcanic activity: evidence from MODIS thermal data. Geophys. Res. Lett. 34, L02304. http:// dx.doi.org/10.1029/2006GL028251.

Hill, D.P., Pollitz, F., Newhall, C., 2002. Earthquake-volcano interactions. Phys. Today 55, $41-47$.

Jay, J.A., Welch, M., Pritchard, M.E., Mares, P.J., Mnich, M.E., Melkonian, K., Aguilera, F., Naranjo, J.A., Sunagua, M., Clavero, J., 2013. Volcanic hotspots of the central and southern Andes as seen from space by ASTER and MODVOLC between the years 2000 and 2010. Geol. Soc. Lond. Spec. Publ. 380, 161-185.

Ji, C., Wald, D.J., Helmberger, D.V., 2002. Source description of the 1999 Hector Mine, California earthquake; Part I: wavelet domain inversion theory and resolution analysis. 92 (4), 1192-1207.

Johnson, J.B., Aster, R.C., 2005. Relative partitioning of acoustic and seismic energy during strombolian eruptions. J. Volcanol. Geotherm. Res. 148, 334-354.

Lavallée, Y., de Silva, S.L., Salas, G., Byrnes, J.M., 2009. Structural control on volcanism at the Ubinas, Huaynaputina, and Ticsani Volcanic Group (UHTVG), southern Peru. J. Volcanol. Geotherm. Res. 186 (3-4), 253-264.

Lay, T., Yue, H., Brodsky, E.E., An, C., 2014. The April 1, 2014 Iquique, Chile Mw 8.1 earthquake rupture sequence. Geophys. Res. Lett. 41 (11), 3818-3825. http://dx.doi.org/ 10.1002/2014GL060238.

Lesage, P., Reyes-Dávila, G., Arámbula-Mendoza, R., 2014. Large tectonic earthquakes induce sharp temporary decreases in seismic velocity in Volcán de Colima, Mexico. J. Geophys. Res. Solid Earth 119, 4360-4376. http://dx.doi.org/10.1002/ 2013JB010884.

Manga, M., Brodsky, E., 2006. Seismictriggering of eruption in the far field: volcanoes and geysers. Annu. Rev. Earth Planet. Sci. 34, 263-291.

Manga, M., Beresnev, I., Brodsky, E.E., Elkhoury, J.E., Elsworth, D., Ingebritsen, S.E., Mays, D.C., Wang, C.-Y., 2012. Changes in permeability caused by transient stresses: field observations, experiments, and mechanisms. Rev. Geophys. 50, RG2004. http://dx. doi.org/10.1029/2011RG000382.

Mastin, L.G., Guffanti, M., Servranckx, R., Webleyd, P., Barsotti, S., Dean, K., Durant, A., Ewert, J.W., Neri, A., Rose, W.I., Schneider, D., Siebert, L., Stunder, B., Swanson, G., Tupper, A., Volentik, A., Waythomas, C.F., 2009. A multidisciplinary effort to assign realistic source parameters to models of volcanic ash-cloud transport and dispersion during eruptions. J. Volcanol. Geotherm. Res. 186 (1-2), 10-21.

Melnik, O., Sparks, R.S.J., 1999. Nonlinear dynamics of lava dome extrusion. Nature 402, 37-41.

Morton, B.R., Taylor, G.T., Turner, J.S., 1956. Turbulent gravitational convection from maintained and instantaneous sources. Philos. Trans. R. Soc. Lond. A 234, 1-23.

Nostro, C., Stein, R.S., Cocco, M., Belardinelli, M.E., Marzocchi, W., 1998. Two-way coupling between Vesuvius eruptions and southern Apennine earthquakes, Italy, by elastic stress transfer. J. Geophys. Res. 103 (10), 24487-24504.

Ottemöller, L., 2008. Seismic hybrid swarm precursory to a major lava dome collapse: 912 July 2003, Soufrière Hills Volcano, Montserrat. J. Volcanol. Geotherm. Res. 177 (4), 903-910.

Rivera, M., 1997. El volcán Ubinas (sur del Perú): Geología, historia eruptiva y evaluación de amenazas volcánicas actuales. Tesis profesional. Univ. Nac, De San Marcos, Lima, Perú.

Rivera, M., Thouret, J.C., Mariño, J., Berolatti, R., Fuentes, J., 2010. Characteristics and management of the 2006-2008 volcanic crisis at the Ubinas volcano (Peru). J. Volcanol. Geotherm. Res. 198 (1-2), 19-34.

Rivera, M., Thouret, J.C., Samaniego, P., Le Pennec, J.L., 2014. The 2006-2009 activity of the Ubinas volcano (Peru): petrology of the 2006 eruptive products and insights into genesis of andesite magmas, magma recharge and plumbing system. J. Volcanol. Geotherm. Res. 270, 122-141.

Shinohara, H., 2008. Excess degassing from volcanoes and its role on eruptive and intrusive activity. Rev. Geophys. 46 (4), RG4005. http://dx.doi.org/10.1029/ 2007RG000244.

Sparks, R.S.J., Bursik, M.I., Carey, S.N., Gilbert, J., Glaze, L.S., Sigurdsson, H., Woods, A., 1997. Volcanic Plumes. John Wiley and Sons, p. 574.

Stern, C.R., 2004. Active Andean volcanism: its geologic and tectonic setting. Rev. Geol. Chile 31 (2), 161-206.

Thouret, J.-C., Davilla, J., Eissen, J.-P., May 1999. Largest explosive eruption in historical times in the Andes at Huaynaputina volcano, A.D. 1600, southern Peru. Geology 27 (5), 435-438. 
Thouret, J.C., Rivera, M., Worner, G., Gerbe, M.C., Finizola, A., Fornari, M., Gonzales, K. 2005. Ubinas: the evolution of the historically most active volcano in southern Peru. Bull. Volcanol. 67 (6), 557-589.

Tilling, R.I., 2009. Volcanism and associated hazards: the Andean perspective. Adv. Geosci. $22,125-137$.

Toda, S., Stein, R.S., Richards-Dinger, K., Bozkurt, S., 2005. Forecasting the evolution of seismicity in southern California: Animations built on earthquake stress transfer. J. Geophys. Res. 110, B05S16. http://dx.doi.org/10.1029/2004JB003415.

White, R., 2011. Monitoring volcanoes and forecasting eruptions. Volcano Observatory Best Practices Workshop: Eruption Forecasting, 11-15 September 2011, Erice, Italy.
White, R., Miller, A., Lynch, L., Power, J., 1998. Observations of hybrid seismic events at Soufriere Hills Volcano, Montserrat: July 1995 to September 1996. Geophys. Res. Lett. 25 (19), 3657-3660.

Wilson, L., Sparks, R.S.J., Huang, T.C., Watkins, N.D., 1978. The control of volcanic column heights by eruption energetics and dynamics. J. Geophys. Res. 83, 1829-1836.

Wooster, M.J., Zhukov, B., Oertel, D., 2003. Fire radiative energy for quantitative study of biomass burning: derivation from the BIRD experimental satellite and comparison to MODIS fire products. Remote Sens. Environ. 86 (1), 83-107. 